\title{
Rancang Bangun Miniatur Pembangkit Listrik Tenaga Mikrohidro Dibengkel Teknik Listrik Universitas Batanghari Jambi
}

\author{
Ottentri $^{1}$, Hendi Matalata ${ }^{2}$ \\ 1,2Program Studi Teknik Elekro, Fakultas Teknik, Universitas Batanghari \\ Correspondence email: otentri00345@gmil.com
}

\begin{abstract}
Abstrak. Kebutuhan akan energy listrik merupakan kebutuhan yang tidak dapat ditawar-tawar lagi untuk kehidupan yang layak bagi setiap orang pada zaman sekarang ini. Umumnya daerah pedesaan terpencil yang terletak pada daerah pegunungan mempunyai potensi energi air yang besar, sehingga pembangkit listrik tenaga air skala mikro merupakan salah satu sumber energi yang dapat dikembangkan. Jambi merupakan daerah yang dilingkupi aliran sungai Batanghari. Penelitian ini bertujuan untuk mangetahui bagaimana proses kerja pembangkit listrik tenaga mikrohidro. Komponen komponen penting dari miniature pembangkit listrik tenaga mikrohidro adalah waduk, pipa pesat, turbin, generator dimana komponen ini tidak bias lepas, saling berkaitan satu sama lain. Putaran tubin diperoleh dari percobaan adalah sebesar $400 \mathrm{rpm}$ dengan debit air 0,0016 m3/s. Tegangan maksimum yang dihasilkan generator adalah sebesar 18 volt. Tegangan yang dihasilkan dari generator untuk mengecas batrai yang digunakan inverter sebesar 13,1 volt. Beban akan tetap nyala walaupun sumber energy utama yaitu generator berhenti beroprasi karna menggunakan energy keduaya itu batrai.
\end{abstract}

Kata kunci: pembangkit listrik; mikrohidro

Abstract. The need for electrical energy is a necessity that can not be ditawar-tawar anymore for a life worthy of every person in this day. Generally, remote rural areas located in mountainous areas have a large potential of water energy, so that the hydroelectric power plant is one of the energy sources that can be developed. Jambi is an area covered with Batanghari River flows. This research aims to know how the work process of Microhydro power plant. Components of the essential components of miniature microhydro power plants are reservoirs, rapid pipes, turbines, generators where these components are not loose bias, interrelated to one another. Round of Tubin obtained from the experiment is $400 \mathrm{rpm}$ with water discharge $0.0016 \mathrm{~m} 3 / \mathrm{s}$. The maximum voltage generated by the generator is 18 volts. Voltage generated from the generator to charging the Batrai used inverter of 13.1 volts. The load will remain on even though the main energy source is the generator stop in the same, because the energy of the second is Batrai.

Keywords: power generation; Small Hydro

\section{PENDAHULUAN}

Energi listrik merupakan energi yang tidak bisa lepas dari kehidupan masyarakat. Kegiatan manusia dengan listrik menjadi lebih lancar, penyebaran informasi menjadi lebih cepat dan mudah, serta dapat meningkatkan kesejahteraan manusia.

Daerah pedesaan terpencil yang sebagian besar daerahnya belum terjangkau jaringan Perusahaan Listrik Nasional (PLN) merupakan suatu masalah bagi pembangunan dan pengembangan masyarakat pedesaan. Kebutuhan akan energi listrik merupakan kebutuhan yang tidak dapat ditawar-tawar lagi untuk kehidupan yang layak bagi setiap orang pada zaman sekarang ini.

Umumnya daerah pedesaan terpencil yang terletak pada daerah pegunungan mempunyai potensi energi air yang besar, sehingga pembangkit listrik tenaga air skala mikro merupakan salah satu sumber energi yang dapat dikembangkan.

Dari sinilah penulis mendapatkan ide untuk membuat sebuah miniatur pembangkit listrik sederhana yang dapat dikembangkan untuk pembangkitan listrik rumah tangga di pedesaan terpencil sehingga rumah tangga yang berada di pedesaan dapat menghasilkan energi listrik untuk diri mereka sendiri dan bekerja secara unkontinu.

Rumusan masalah pada latar belakang di atas adalah sebagai berikut: 1) Pembuatan Pembangkit Listrik Tenaga Mikrohidro (PLTMH) yang sederhana dan dapat langsung dimanfaatkan sebagai energi listrik rumah tangga; 2) pembuatan Pembangkit Listrik Tenaga Mikro Hidro (PLTMH) dari energi kenetik menjadi energi listrik.

Tinjauan Umum Pembangkit Listik Tenaga Mikro Hidro
Pembangkitan listrik mikrohidro adalah pembangkitan listrik dihasilkan oleh generator listrik DC atau AC.Mikrohidro hanyalah sebuah istilah. Mikro artinya kecil sedangkan Hidro artinya air. Dalam prakteknya istilah ini tidak merupakan sesuatu yang baku namun Mikro Hidro, pasti menggunakan air sebagai sumber energinya.

Pembangkit Listrik Tenaga Mikro Hidro (PLTMH), juga mempunyai suatu kelebihan dalam hal biaya operasi yang rendah jika dibandingkan dengan Pembangkit Listrik seperti Pembangkit Listrik Tenaga Diesel (PLTD), Pembangkit Listrik Tenaga Uap (PLTU) dan Pembangkit Listrik lainnya karena Mikro Hidro 
memanfaatkan energi sumber daya alam yang dapat diperbarui, yaitu sumber daya air. Dengan ukurannya yang kecil penerapan Mikro Hidro relatif mudah dan tidak merusak lingkungan. Rentang penggunaannya cukup luas, terutama untuk menggerakkan peralatan atau mesin-mesin yang tidak memerlukan persyaratan stabilitas tegangan yang akurat.

PLTMH adalah termasuk dalam kategori PLTA (Pembangkit Listrik Tenaga Air), karena prinsip kerja dan cara pembuatan PLTMH tersebut sama dengan PLTA umumnya. PLTMH juga dapat dikatakan sebagai PLTA berkapasitas kecil. Akhir - akhir ini di dunia, termasuk negara-negara maju, banyak terdapat pembangunan PLTA berkapasitas kecil. Pembagian PLTA dengan kapasitas kecil pada umumnya adalah sebagai berikut:

1. PLTA Mikro $<100 \mathrm{~kW}$

2. PLTA Mini $100-999 \mathrm{~kW}$

3. PLTA Kecil $1000-10000 \mathrm{~kW}$

Salah satu sebab bagi negara-negara maju membangun PLTA berkapasitas kecil ini adalah dikarenakan harga minyak yang terus meningkat, dan di samping bertambahnya kebutuhan listrik di negaranegara maju.

Secara teknis, pembangkit listrik tenaga mikrohidro memiliki tiga komponen utama yaitu air (sebagai sumber energi), turbin dan generator. Pembangkit listrik tenaga mikrohidro mendapatkan energi dari aliran air yang memiliki perbedaan ketinggian tertentu. Pada dasarnya, pembangkit listrik tenaga mikrohidro memanfaatkan energi potensial jatuhan air (head). Semakin tinggi jatuhan air maka semakin besar energi potensial air yang dapat diubah menjadi energi listrik.

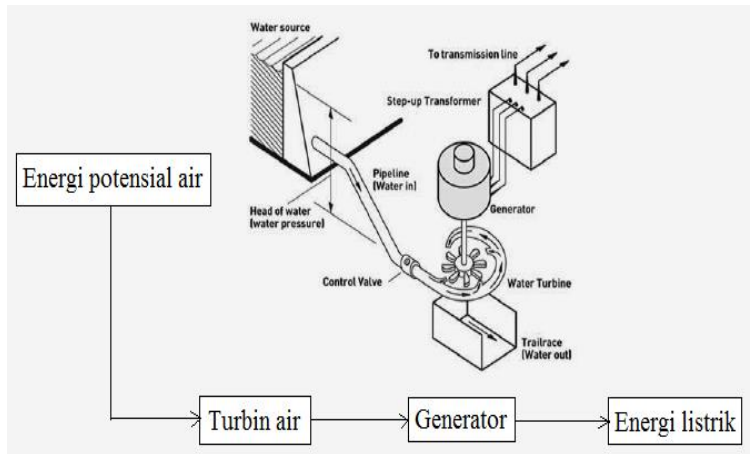

Gambar 1. Prinsip Kerja PLTMH

Pembangkit listrik tenaga mikrohidro bisa memanfaatkan ketinggian air yang tidak terlalu besar, misalnya dengan ketinggian air 2,5 m dapat dihasilkan listrik 400 W. Prinsipkerja PLTMH adalah memanfaatkan beda tinggi dan jumlah debit air per detik yang ada pada aliran atau sungai. Air yang mengalir melalui intake dan diteruskan oleh saluran pembawa hingga penstock, akan memutar poros turbin sehingga menghasilkan energy mekanik. Turbin air akan memutar generator dan menghasilkan listrik.

\section{Energi Potensial}

Energi potensial adalah energi yang dimiliki oleh suatu benda karena kedudukan atau posisi benda tersebut. Energi potensial tersimpan dalam benda tersebut dan dimanfaatkan ketika diperlukan.

Energi potensial gravitasi adalah energi potensial yang disebabkan oleg gaya gravitasi bumi. Jika Anda memegang sebauh batu dengan massa $\mathrm{m}$ pada ketinggian h dari tanah atau lantai, kemudian batu tersebut Anda lepas tanpa kecepatan awal, maka benda akan jatuh dan membentur tanah atau lantai. Benda itu sudah melakukan usaha terhadap tanah atau lantai.

Secara sederhana, energi potensial gravitasi suatu benda bermassa $m$ terhadap satu bidang acuan adalah sebagai hasil kali berat benda tersebut dengan ketinggian benda dari bidang acuan (tanah, lantai, dan lain-lain). Secara matematis, energi potensial dapat dirumuskan dengan perhitungan berikut:

$$
\begin{aligned}
& \mathrm{EP}=\mathrm{m} \cdot \mathrm{g} \cdot \mathrm{h} \\
& \text { Keterangan: } \\
& \text { EP : Energi potensial } \\
& \mathrm{m} \text { : Massa benda } \\
& \text { g : Gravitasi bumi } \\
& \mathrm{h} \text { : Tinggi benda }
\end{aligned}
$$

\section{Potensi Tenaga Air}

Dalam PLTA, potensi air dikonversikan menjadi tenaga listrik. Mula-mula potensi tenaga air dikonversi menjadi tenaga mekanik untuk memutar turbin, kemudian turbin akan memutara generator yang dapat menghasilkan listrik.

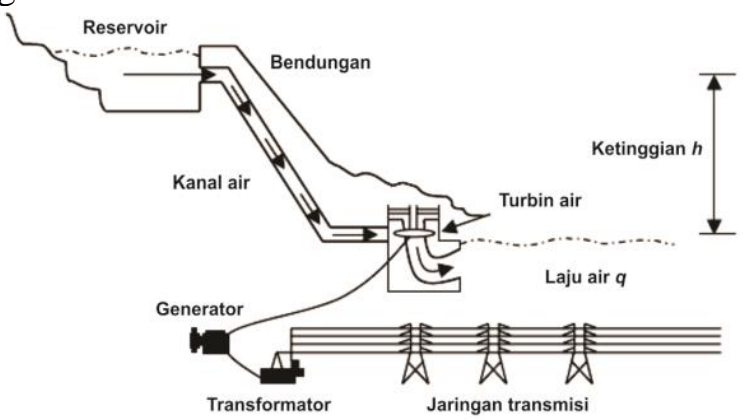

Gambar 2. prinsip kerja PLTA

Adapun persamaan atas Daya yang dibangkitkan generator yang diputar oleh Turbin Air adalah:

$\mathrm{P}=\mathrm{k} \cdot \eta \cdot \mathrm{H} \cdot \mathrm{q} \cdot[\mathrm{kW}]$

Dimana:

$\mathrm{P} \quad=$ daya $[\mathrm{kW}]$

$\mathrm{H} \quad=$ tinggi air terjun (meter)

$\mathrm{q}=$ debit air $\left[\mathrm{m}^{3} /\right.$ detik $]$

$\eta \quad=$ efesiensi turbnin bersama generator

$\mathrm{k} \quad=$ konstanta 


\section{Turbin}

Terdapat dua jenis turbin air (PLTA,PLTMH) yaitu:

1. turbin impulse

2. turbin reaksi.

Type Turbin ini dipengaruhi oleh "head" atau tinggi dari air terhadap turbin dan debit atau volume air di lokasi Pembangkit. Faktor lain yang mempengaruhi adalah efisiensi dan biaya.

\section{Generator}

Generator adalah suatu sistem yang menghasilkan tenaga listrik dengan masukan tenaga mekanik. Jadi disini generator berfungsi untuk mengubah tenaga mekanik menjadi tenaga listrik yang mempunyai prinsip kerja sebagai berikut:

"Bilamana rotor diputar maka belitan kawatnya akan memotong gaya-gaya magnit pada kutub magnit, sehingga terjadi perbedaan tegangan, dengan dasar inilah timbullah arus listrik, arus melalui kabel/kawat yang ke dua ujungnya dihubungkan dengan cincin geser. Pada cincin-cincin tersebut menggeser sikatsikat, sebagai terminal penghubung keluar.“

\section{Rotor}

Bagian-bagian generator:

Rotor adalah adalah bagian yang berputar yang mempunyai bagian terdiri dari poros, inti, kumparan, cincin geser, dan sikat-sikat.

Stator adalah bagian yang tak berputar (diam) yang mempunyai bagian terdiri dari rangka stator yang merupakan salah satu bagian utama dari generator yang terbuat dari besi tuang dan ini merupakan rumah dari semua bagian-bagian generator, kutub utama beserta belitannya, kutub-kutub pembantu beserta belitannya, bantalan-bantalan poros.

Macam Generator:

Berdasarkan tegangan yang dibangkitkan generator dibagi menjadi 2 yaitu :

1. Generator Arus Bolak-Balik (AC)Generator arus bolak-balik yaitu generator dimana tegangan yang dihasilkan (tegangan output) berupa tegangan bolakbalik.

2. Generator Arus Searah (DC)Generator arus searah yaitu generator dimana tegangan yang dihasilkan (tegangan output) berupa tegangan searah, karena didalamnya terdapat sistem penyearahan yang dilakukan bisa berupa oleh komutator atau menggunakan dioda.

\section{METODE}

\section{Tempat dan Waktu}

Perancangan alat di lakukan di bengkel fakultas teknik listrik Universitas Batanghari Jambi, pada hari kamis 20 juni 2019 sampai 20 juli 2019.

\section{Diagram Alur}

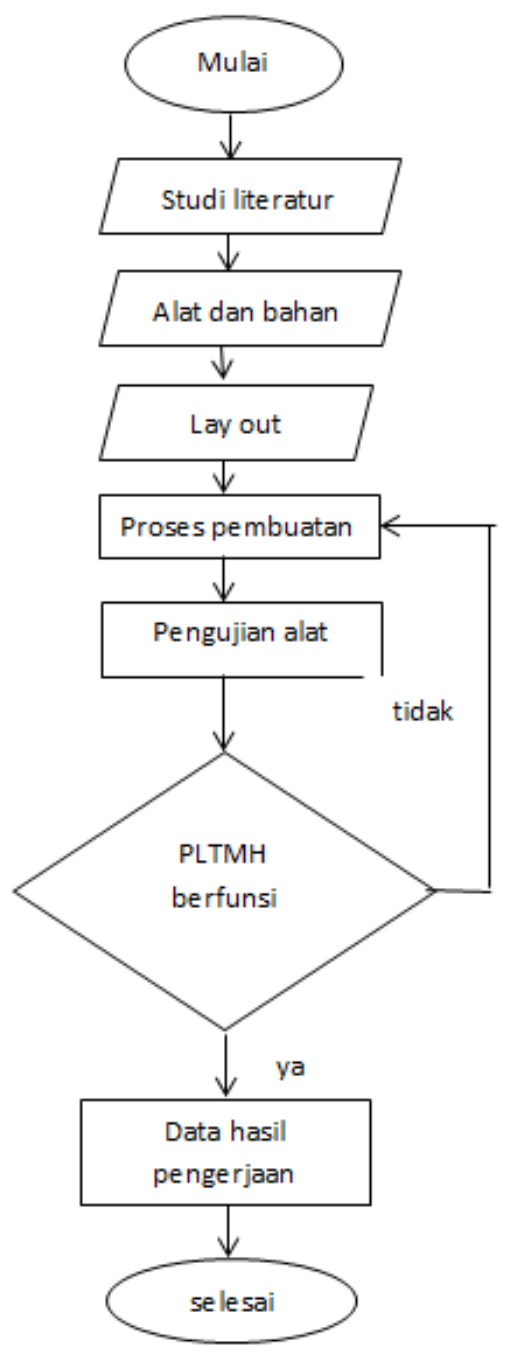

Gambar 3. Diagram Alur

\section{Studi Literatur}

Mencari referensi miniatur Pembangkit Listrik Tenaga Mikro Hidro (PLTMH), bertujuan untuk mengetahui apa saja yang harus lakukan sebelum melakukan pekerjaan

\section{Alat dan Bahan}

Setelah mencari referensi, barulah menyiapkan alat alat apa saja yang di butuhkan, utuk mempermudah pekerjaan dan bahan bahan apa saja yang dibutuhkan. Adapun alat yang di butuhkan adalah:

1. Tang

2. Gerinda

3. Mesin las

4. Alat ukur

5. Bor

Adapun bahan yang di butuhkan adalah:

1. Generator

2. Besi siku

3. Plat

4. gear

5. Sendok nasi 
6. Pipa 2 inc

7. Waduk

8. Triplek

9. Baut

\section{Layout}

Merencanakan apa saja yang akan dikerjakan agar proses pekerjaan menjadi mudah.

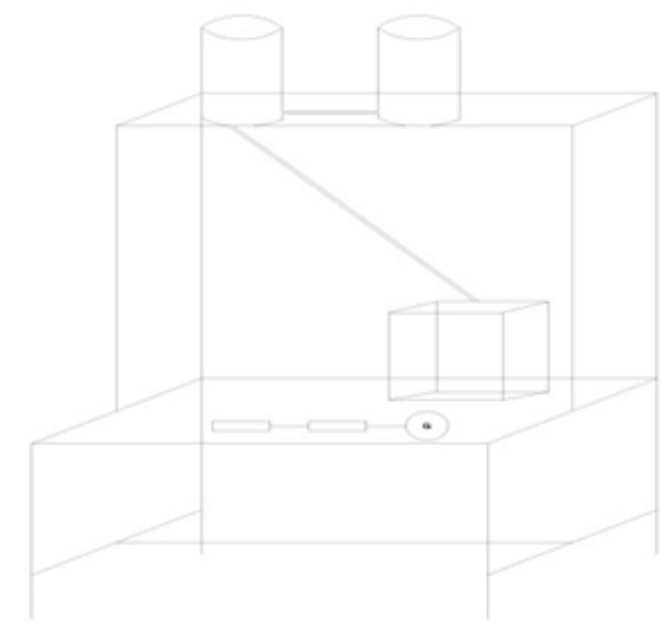

Gambar 4. Layout

\section{Proses Pembutan}

Bagai mana proses pembutan pembangkit listrik tenaga mikro hidro dengan perencanaan alat dan bahan yang telah disiapkan dari awal hingga selesai.

\section{Pengujian Alat}

Melakukan pengujian Pembangkit Listrik Tenega Mikro Hidro (PLTMH) yang telah kerjakan, jika berhasil maka bisa di ambil data hasil pengujian tersebut, tapi jika gagal maka, harus di periksa kembali rancangan yang telah di pasang tersebut mulai dari awal hingga selesai.

\section{PLTMH Berfungsi}

Dapat diketahui apabila semua rangkaian telah benar dan bekerja dengan semestinya, apa bila terjadi kesalahan pada rangkaian alat tidak akan berfungsi, harus di lakukan pengecekan ulang.

\section{Data Hasil Pengujian}

Data hasil pengujian dapat diambil ketika alat bekerja dengan benar sesuai dengan apa yang dirangcang.

\section{HASIL DAN PEMBAHASAN \\ Rancang Bangun Miniatur Pembangkit Listrik Tenga Mikro Hidro}

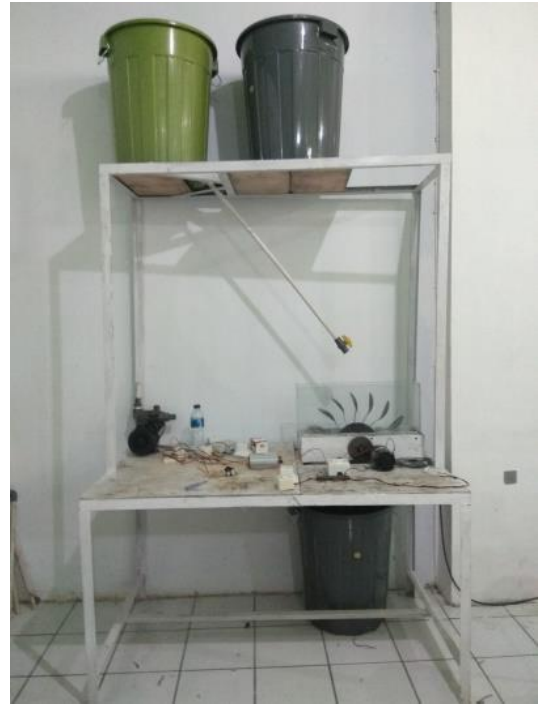

Gambar 5. Miniatur PLTMH

Pada peneliian rancang bangun miatur pembangkit listrik adapun tinggi keserluruhan meja adalah $210 \mathrm{~cm}$ dan lebar $80 \mathrm{~cm}$, waduk yang di gunakan adalah 2 buah baskom 70 liter, pipa pesat yang digunakan adalah pipa $1 / 2$ inci, turbin yang digunakan turbin pelton, dan transmisi yang digunakan adalah gear 1 berbanding 4 untuk mempercepat putaran generator.

\section{Cara Pengoperasian}

1. Pastikan waduk terisi penuh

2. Membuka keran air untuk memutar turbin

3. Dari putaran turbin di percepat dengan transmisi untuk menyalakan generator

4. generator yang mengubah energi gerak menjadi energi listik

5. Keluaraan dari generator menyimpan listrik di batrai

6. Keluaran lisrik dari batrai di ubah teganganya mengunakan inverter

7. Keluran listrik dari inverter menyalakan lampu dan mesin air untuk mengisi waduk agar air didalam waduk selalu terisi

\section{Hasil Pengujian \\ Debit Air}

Debit air yang diproleh dari hasil pengukuran miniatur Pembangkit Listrik Tenaga Mikro Hidro adalah 24,56 Liter/Menit atau 0,41 Liter/Detik

$$
\text { Debit }=\frac{\text { Volume }}{\text { Waktu }} \boldsymbol{Q}=\frac{\boldsymbol{V}}{\boldsymbol{t}}
$$

Diketahui

$$
\begin{aligned}
& \mathrm{V} \quad=140 \text { Liter } \\
& \mathrm{T} \quad=5,37 \text { menit }=337 \text { Detik } \\
& \text { Jawab: } \\
& \begin{array}{r}
\mathrm{Q}=\frac{140}{5,37}=24,56 \text { Liter } / \text { Menit }=\frac{140}{337} \\
=0,41 \text { Liter } / \text { Menit }
\end{array}
\end{aligned}
$$


Ottentri dan Hendi Matalata, Rancang Bangun Miniatur Pembangkit Listrik Tenaga Mikrohidro Dibengkel Teknik Listrik Universitas Batanghari Jambi

\section{Energi Potensial}

Secara matematis, energy potensial dapat dirumuskan dengan perhitungan berikut:

$\mathrm{EP}=\mathrm{m} \cdot \mathrm{g} \cdot \mathrm{h}$

Keterangan:

EP : Energi potensial

$\mathrm{m}$ : Massa benda

g : Gravitasi bumi

$\mathrm{h} \quad$ : Tinggi benda

Dimana:

$\mathrm{EP} \quad=\ldots \mathrm{J}$

$\mathrm{M} \quad=140 \mathrm{~kg}$

g $\quad=9,807 \mathrm{~m} / \mathrm{s} 2$

$\mathrm{h} \quad=1,3 \mathrm{~m}$

Jawab

$140,807 \times 130=178.487,4$ joule

\section{Potensi Tenaga Air}

Adapun persamaan atas Daya yang dibangkitkan generator yang diputar oleh Turbin Air adalah:

$\mathrm{P}=\mathrm{k} \cdot \eta \cdot \mathrm{H} \cdot \mathrm{q} \cdot[\mathrm{kW}]$

Keterangan:

$\mathrm{P} \quad=$ daya $[\mathrm{kW}]$

$\mathrm{H} \quad=$ tinggi air terjun (meter)

$\mathrm{q}=$ debit air $\left[\mathrm{m}^{3} /\right.$ detik $]$

$\eta \quad=$ efesiensi turbin bersama generator

$\mathrm{k} \quad=$ konstanta

Dimana:

$\mathrm{P} \quad=\ldots \mathrm{Kw}$

$\mathrm{H} \quad=1,3$ Meter

$\mathrm{Q} \quad=0,00116$

$\mathrm{h} \quad=0,95$

$\mathrm{k} \quad=9,8$

Jawab:

$9,8 \times 0,95 \times 1,3 \times 0,00116=0,0140 \mathrm{~kW}$

$=0,0140 \times 1000=14,03$ watt

\section{Putaran Turbin}

Putaran turbin yang di dapat adalah 100-105 rpm lalu di percepat menggunakan transmisi 1 berbanding 4 .

$$
\begin{aligned}
& 100 \times 4=400 \mathrm{rpm} \\
& 105 \times 4=420 \mathrm{rpm}
\end{aligned}
$$

Jadi rpm yang di dapatkan adalah 400-420 rpm

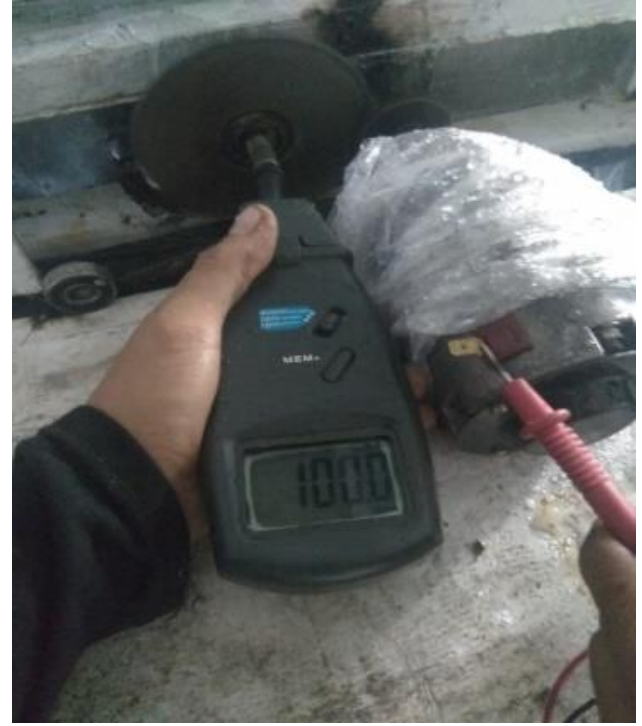

Gambar 6. Hasil Putaran Tubin

\section{Generator DC}

Pengujian yang di lakukan pada generator DC adalah pengujian berbeban dan pengujian tidak berbeban, hasil pengujian adalah sebagai berikut:

Tabel 1. Pengujian Generator DC

\begin{tabular}{ccccc}
\hline $\begin{array}{c}\text { Debit } \\
\text { air }\end{array}$ & RPM & $\begin{array}{c}\text { Tanpa beban } \\
\text { volt }\end{array}$ & \multicolumn{2}{c}{ Berbeban 25 watt } \\
ampere & volt \\
\hline 0,41 & 400 & 18 & 1,1 & 9,5 \\
\hline
\end{tabular}

\section{Pengujian Berbeban}

Pada pengujian berbeban menggunakan 2 buah lampu 5 watt,dan 1 buah lampu 15watt adapun hasil yang didapat pada pengujian minatur PLTMH dapat di lihat pada tabel di bawah:

Tabel 2. Pengujian Minatur PLTMH

\begin{tabular}{lcccc}
\hline No & Beban & DC & Tegangan & Arus Daya \\
\hline 1 & 5 Watt & 13 & 0,8 & 10,4 \\
2 & 10 Watt & 12 & 0,9 & 10,8 \\
3 & 15 Watt & 11 & 1 & 11 \\
4 & 20 Watt & 10 & 1 & 10 \\
5 & 25 Watt & 9,5 & 1,1 & 10,4 \\
\hline
\end{tabular}

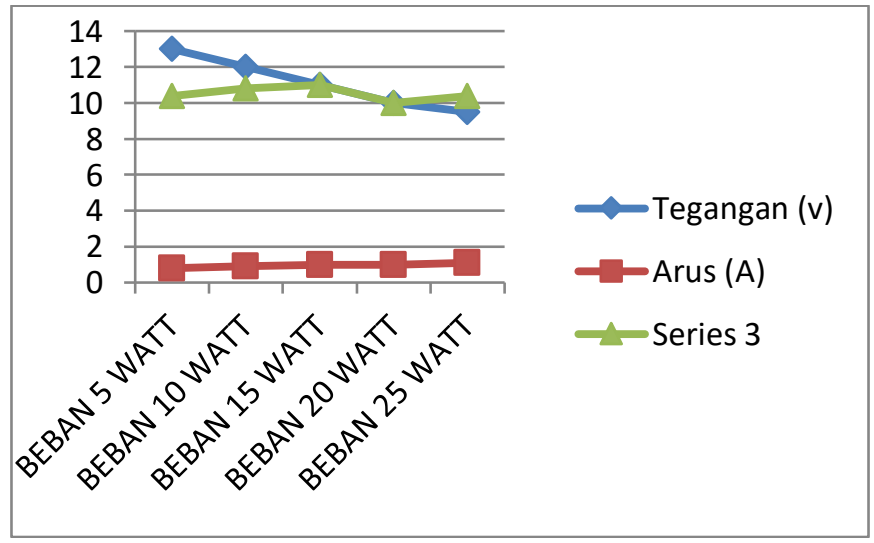

Gambar 7. Grafik Beban DC 


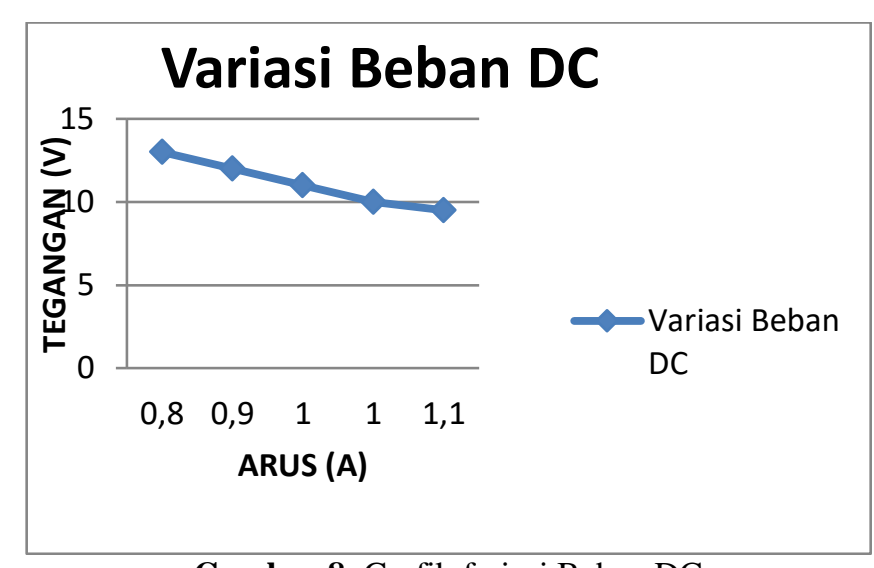

Gambar 8. Grafik fariasi Beban DC

\section{Batrai 12 VOLT}

Pada pengujian ini batrai di gunakan sebagai beban, dimana tegangan keluran dari generator sebagai sumber listrik untuk mengecas batrai. Hasil dari keluaran generator jika mengecas batrai 12 volt diukur dangan menggunakan volt ampere digital adalah 13,1 volt dan 0,9 ampere, hasil pengujian dapat dilihat pada gambar di bawah.

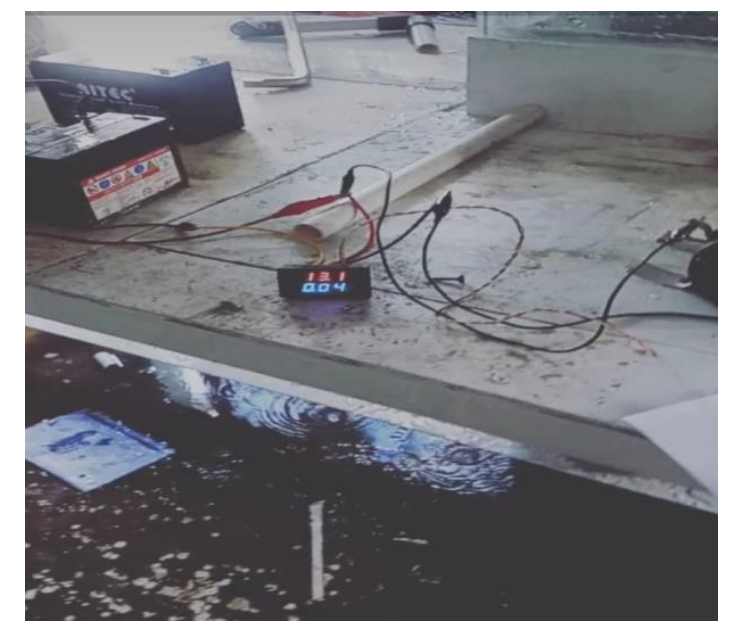

Gambar 9. Batrai Sebagai Beban

\section{Inverter}

Inverter digunakan untuk mengkonversikan sumber arus serah (DC) menjadi sumber arus bolak balik (AC) Hasil dari keluran batrai 12 Volt DC menjadi 220 Volt AC yang digunakan untuk meghidupkan pompa air dan 3 buah lampu AC 5 WATT

\section{SIMPULAN}

Dari percobaan rancang bangun miniature pembangkit listrik tenaga mikrohidro, dapat di ambil kesimpulan sebagai berikut:

1. Komponen komponen penting dari pembangkit listrik tenaga mikrohidro adalah waduk, pipa pesat, turbin, generator dimana komponen ini tidak bias lepas, saling berkaitan satu sama lain

2. Putaran tubin diperoleh dari percobaan adalah sebesar $400 \mathrm{rpm}$ dengan debit air $0,0016 \mathrm{~m} 3 / \mathrm{s}$
3. Tegangan maksimum yang dihasilkan generator adalah sebesar 18 volt

4. Tegangan yang dihasilkan dari generator untuk mengecas batrai yang digunakan inverter sebesar 13,1 volt

5. Beban akan tetap nyala walaupun sumber energy utama yaitu generator berhenti beroprasi karna menggunakan energy kedua yaitu batrai

\section{DAFTAR PUSTAKA}

[1] Jack, Fritz.1984, Small and Mini Hydropower System, McGraw-Hill, New York.

[2] Ir. Djiteng Marsudi 2005 Pembangkitan Energi Listrik, Balai Penerbit Humas ISTN Bhumi Serengseng Indah.

[3] Kevin muhamad, 2017/09/22. Journal PLTMH Pembangkit Listrik Tenaga Mikro Hidro, Surabaya

[4] Haimerl, L.A.(1960). The Cross Flow Turbine. Jerman Barat

[5] Ardinathasanjaya, 2017/04/28, Generator AC and DC, Semarang 